\title{
DAMPAK KEBERADAAN PT. PERDANA SAWIT PLANTATION (PSP) TERHADAPSOSIAL EKONOMI MASYARAKAT
}

\author{
PAULUS \\ Fakultas Ilmu Sosial dan Ilmu Politik Universitas Kapuas Sintang \\ paulus_semari@yahoo.com \\ Universitas Kapuas Sintang, Jl. Y.C. Oevang Oeray, No.92 Sintang Kalimantan Barat
}

\begin{abstract}
Abstrak: Permasalahan penelitian ini adalah dampak yang ditimbulkan oleh perusahaan PT. Perdana Sawit Plantation yang bergerak dibidang perkebunan kelapa sawit yang beroperasi di wilayah kecamatan Ketungau Tengah. Penelitian ini merupakan penelitian deskriptif dengan analisis kualitatif. Tujuan penelitian ini adalah untuk menemukan data dan menganalisis data yang diperoleh kemudian dibuat kesimpulan dan saran atas penelitian yang dilakukan. Aspek yang diteliti berkaitan dengan permaslahan adalah aspek sosial dan aspek ekonomi. Teknik pengumpulan data berupa wawancara, observasi dan dokumentasi. Subjek penelitian ini antara lain : 1). General Manager, 2). Manager Community Development, 3). Kepala Desa Argo Mulyo, dan 4). Tokoh Masyarakat.

Hasil penelitian diperoleh data bahwa perusahaan telah melaksanakan operasinya sesuai dengan ketentuan hukum yang berlaku. Perusahaan telah melaksanakan program CSR (Corporate Social Responsibilty) sebagai bentuk tanggung jawab sosial perusahaan kepada semua pihak-pihak terkait, baik internal maupun eksternal. Namun program yang dijalankan belum sepenuhnya dapat terlaksana sesuai dengan harapan masyarakat. Pada aspek sosial, perusahaan telah memberikan kontribusi berupa bantuan sarana dan prasarana bagi masyarakat setempat, terlibat dalam berbagai even sosial budaya masyarakat seperti keterlibatan di dalam kegiatan budaya masyarakat. Partisipasi dalam bentuk tenaga, barang, dan juga uang. Partisipasi sosial juga diwujudkan dalam bentuk bantuan pembangunan sarana dan prasarana umum untuk pemerintahan desa. Pada aspek ekonomi, perusahaan telah memberikan kontribusi berupa memberikan peluang kerja bagi masyarakat untuk menjadi pegawai sehingga dapat memperoleh pendapatan untuk meningkat taraf hidup masyarakat. Namun demikian secara umum kontribusi perusahaan belum menyentuh sepenuhnya terhadap kebutuhan masyarakat. Tanggung jawab sosial perusahaan masih dianggap belum sesuai dengan harapan masyarakat.
\end{abstract}

Kata Kunci : Dampak, Perusahaan, Sosial, Ekonomi.

Pembangunan nasional dilaksanakan bertujuan untuk kemajuan dan pemerataan pembangunan dibidang ekonomi dan sosial masyarakat Indonesia yang adil dan makmur berdasarkan pancasila. Pembangunan dibidang ekonomi dan sosial dimaksudkan agar masyarakat dapat menikmati kesejahteraan, tanpa terkecuali baik masyarakat perkotaan maupun pedesaan. Program pemerintah di dalam pembangunan terdiri dari berbagai sektor yang ditangani oleh masingmasing kementerian Republik Indonesia. Bidang pertanian dan perkebunan merupakan salah satu andalan pemerintah untuk memberikan kontribusi pada Pendapatan Domestik Bruto. Sebagai Negara agraris, rakyat Indonesia sebagian besar aktivitas masyarakatnya masih dibidang pertanian dan perkebunan. Masyarakat yang mengeluti bidang pertanian dan perkebunan tersebut ada yang berprofesi sebagai petani dan pekebun serta yang lebih banyak adalah sebagai karyawan atau buruh di perusahaan-perusahaan perkebunan.Pulau-pulau di Indonesia, khususnya Pulau Kalimantan menjadi tempat pengembangan bisnis kelapa sawit yang potensial mengingat lahan yang cocok dan masih memungkinkan untuk pengembangan dan perluasan areal perkebunan. Namun demikian, dalam dasawarsa terakhir ini hutan di Kalimantan sudah semakin menipis mengingat perambahan hutan untuk pembukaan lahan perkebunan serta perambahan hutan berupa ilegal loging yang masih marak terjadi sampai sekarang. Kegiatan perkebunan kelapa sawit berskala besar memerlukan hamparan lahan berjuta-juta hektar sehingga hutan di Kalimantan sepuluh sampai dua puluh tahun yang akan datang diperkirakan akan habis. Keberadaan perkebunan kelapa sawit bagi masyarakat tentu memiliki dampak, baik dampak positif maupun dampak negatif.

Dampak positif yang dapat dinikmati oleh masyarakat seperti adanya lapangan kerja yang dapat menyerap tenaga kerja di wilayah dimana perusahaan beroperasi. Meningkatnya pendapatan masyarakat, serta terbukanya daerah terisolir dengan adanya jalan tembus antar desa yang dibuat oleh perusahaan untuk aktivitasnya. Selain itu program Corporate Social Responsibility (CSR) dari perusahaan berupa program pembangunan, baik pembangunan fisik maupun non fisik di desa. Sementara disisi lain, keberadaan perusahaan juga menimbulkan dampak negatif yang tidak sedikit. 
Dampak negatif yang berpengaruh besar adalah hilangnya hutan yang selama ini sebagai tempat hidup makhluk hidup dan konservasi tanah dan air. Hewan-hewan menjadi terganggu habitatnya sehingga dapat mengancam keberlangsungan hidupnya sehingga beberapa jenis hewan menjadi punah. Berkurangnya kawasan hutan dalam skala besar juga berpengaruh terhadap keseimbangan ekosistem di alam secara keseluruhan. Dampak yang dirasakan kita secara langsung akibat dari hilangnya hutan adalah terjadinya pemanasan global yang ditandai dengan peningkatan intensitas suhu yang selanjutnya dapat menimbulkan berbagai bencana seperti banjir, tanah longsor, badai angin dan berbagai bencana alam lainnya.

Persoalan lain yaitu dari aspek sosial budaya, keberadaan perkebunan dapat saja menimbulkan pergeseran nilai sosial budaya pada masyarakat. Gaya hidup dan pergaulan yang tidak sehat dari beberapa karyawan yang ada diperusahaan dapat mempengaruhi perilaku masyarakat, terutama anak-anak dan para remaja yang ada di daerah di desa sekitar perusahaan. Namun tidak dapat digeralisasi juga bahwa semua tempat di perusahaan mengalami persoalanpersoalan sosial seperti yang diuraikan diatas. PT. Perdana Sawit Platation (PSP), merupakan salah perkebunan kelapa sawit milik swasta yang beroperasi di wilayah kecamatan Ketungau Tengah Kabupaten Sintang. Salah satu desa yang berada di wilayah operasi perusahaan adalah desa Agromulyo. Berdasarkan pra penelitian, bahwa keberadaan perusahaan sawit tersebut memiliki andil yang besar di dalam tatanan sosial ekonomi masyarakat. Dengan adanya perusahaan, terbukanya lapangan kerja untuk masyarakat yang ingin mencari pekerjaan. Namun persoalan lain adalah adanya keluhan dari masyarakat mengenai kebijakan perusahaan dalam hal rekrutmen pegawai yang dianggap kurang keberpihakan untuk masyarakat lokal, hal ini terlihat dengan komposisi karyawan tetap dan posisi pemegang jabatan yang lebih banyak dari tenaga kerja luar penduduk setempat.

Sementara tenaga kerja untuk penduduk di wilayah kerja perusahaan lebih banyak berstatus sebagai buruh harian lepas. Persoalan lainnya adalah adanya ketidakpuasan masyarakat yang bermitra ke perusahaan sebagai petani plasma. sistem pembagian dianggap kurang sesuai dan pembagian hasil keuntungan dari produksi buah kelapa sawit juga kurang lancar. Kurangnya komunikasi dan koordinasi tersebut membuat masyarakat tidak puas. Persoalan lainnya adalah masih kurangnya pelaksanaan CSR oleh perusahaan. Perawatan jalan negara yang dilalui perusahaan di wilayah operasinya juga kurang dilakukan, kontribusi pembangunan untuk desadesa juga masih dirasakan kurang. Dampak merupakan suatu akibat dari suatu perbuatan dan peristiwa-peristiwa alam yang telah terjadi. Setiap perbuatan manusia akan menimbulkan sebuah dampak, baik itu dampak positif maupun dampak negatif. Manusia berinteraksi di dalam lingkungan, yaitu interaksi manusia dengan lingkungan alam seperti dengan tanah, hewan dan tumbuhan serta interaksi sesama manusia. Pada penelitian ini peneliti membatasi kajian dampak antar manusia melalui kegiatan perusahaan dan dampaknya terhadap masyarakat dilingkungan perusahaan yang ditinjau secara sosial, budaya, dan ekonomi. Aspek sosial merupakan hubungan atau interaksi manusia dengan manusia yang lainnya di dalam sebuah sistem lingkungan. Sebagai makhluk sosial manusia memerlukan orang lain dalam hidupnya. Keperluan ini seperti kebutuhan akan kasih sayang, perlindungan, penghargaan/pengakuan dan juga untuk mewarisi keturunannya. Aktivitas sosial akan memberikan perubahan bagi individu dalam interaksinya, perubahan yang terjadi dapat berupa perubahan yang baik dan yang tidak baik. Aktivitas sosial yang terjadi di masyarakat melalui proses interaksi sosial dalam jangka waktu tertentu, dan biasanya terjadi dalam waktu yang cukup lama sehingga menimbulkan sebuah pengaruh antara indivu yang satu dengan yang lain di lingkungan masyarakat.

Menurut Chaplin (2011 : 21) bahwa "interaksi merupakan pertalian sosial antar individu yang sedemikian rupa sehingga individu yang bersangkutan saling mempengaruhi satu sama lainnya". Berdasarkan pendapat tersebut dapat dikatakan bahwa interaksi sosial merupakan kemampuan seorang individu dalam melakukan hubungan sosial dengan individu lain atau kelompok dengan ditandai adanya kontak sosial melalui komunikasi perilaku seseorang. Menurut Mahmudah (2010), faktor-faktor yang mendasari berlangsungnya interaksi sosial antara lain :Faktor imitasi. Yaitu tingkah laku yang terjadi pada individu dipengaruhi oleh orang lain dengan cara meniru tingkah lalu orang lain yang dilihatnya. Faktor sugesti, Faktor sugesti adalah pengaruh psikis, baik yang datang dari dirinya sendiri maupun yang datang dari orang lain yang umumnya diterima tanpa adanya daya kritik. Faktor identifikasi, Identifikasi di dalam psikologi berarti dorongan untuk menjadi identik (sama) dengan orang lain, baik secara fisik maupun non fisik. Proses identifikasi sering kali untuk pertama kali berlangsung secara tidak sadar (secara dengan sendirinya). Selanjutnya bersifat irasional yaitu berdasarkan perasaan atau kecendrungankecendrungan dirinya. Simpati, Simpati adalah perasaan tertariknya orang yang satu dengan orang yang lain. Simpati muncul dalam diri seorang individu tidak atas dasar rasional, melainkan berdasarkan penilaian perasaan.

Tindakan seseorang disebabkan sugesti (gerakan hati) yang dapat dipengaruhi oleh orang 
lain yang berinteraksi dengannya. Pikiran dan perasaan seseorang dipengaruhi oleh apa yang ditangkap dengan panca inderanya. Oleh karena itu apa yang dilihat, didengar dan dirasakannya pada lingkungannya akan dapat mempengaruhi pikiran yang selanjutnya diekspresikan dengan sikap dan perbuatan. Menurut Resita, Herawati, dan Suhadi (2014 : 23), "Kontak sosial dapat berlangsung dalam tiga bentuk yaitu antara orang per orangan, antara orang perorangan dengan kelompok, dan antara suatu kelompok dengan kelompok". Interaksi sosial dapat berdampak luas terhadap sendi-sendi kehidupan di masyarakat seperti distribusi tenaga kerja (kesempatan kerja), pendidikan dan kesehatan masyarakat. Sendi-sendi kehidupan tersebut dapat berubah seiring berubahnya peradaban karena pola pikir dan teknologi yang semakin maju. Kemajuan tersebut tentu akan berdampak terhadap kualitas kehidupan, baik secara fisik, mental dan spiritual di masyarakat. Semakin meningkatnya pembangunan, semakin besar pula kesempatan kerja yang tersedia. Hal ini berarti semakin besar pula permintaan akan tenaga kerja. Sebaliknya semakin besar jumlah penduduk, semakin besar pula kebutuhan akan kesempatan kerja. Tersedianya lapangan/kesempatan kerja baru untuk mengatasi peningkatan penawaran tenaga kerja merupakan salah satu target yang harus dicapai dalam pembangunan ekonomi daerah. Upaya tersebut dapat diwujudkan melalui peningkatan pertumbuhan ekonomi khusus dengan keberadaan perusahaan berskala besar seperti PT. Perkebunan.

Kesempatan kerja secara umum diartikan sebagai suatu keadaan yang mencerminkan jumlah dari total angkatan kerja yang dapat diserap atau ikut serta aktif dalam kegiatan perekonomian. Kesempatan kerja adalah penduduk usia 17 tahun keatas yang bekera atau disebut pekerja. Menurut Esmara (1986:134), kesempatan kerja dapat diartikan sebagai jumlah penduduk yang bekerja atau orang yang sudah memperoleh pekerjaan, semakin banyak orang yang bekerja semakin luas kesempatan kerja. Sedangkan Sagir (1994:52), memberi pengertian kesempatan kerja sebagai lapangan usaha atau kesempatan kerja yang sudah tersedia untuk bekerja akibat dari suatu kegiatan ekonomi, dengan demikian kesempatan kerja mencakup lapangan pekerjaan yang sudah diisi dan kesempatan kerja juga dapat diartikan sebagai partisipasi dalam pembangunan. Sukirno (2000:68), memberikan pengertian kesempatan kerja sebagai suatu keadaan dimana semua pekerja yang ingin bekerja pada suatu tingkat upah tertentu akan dengan mudah mendapat pekerjaan. Berdasarkan definisi di atas penulis dapat menyimpulkan bahwa kesempatan kerja adalah penduduk yang berusia produktif yang sedang memiliki pekerjaan atau tidak memiliki pekerjaan atau sedang mencari pekerjaan. Setiap individu memiliki kemampuan yang berbeda- beda antara satu dengan lainnya. Menurut Mohammad Zain Milman (Yusdi 2010:10) mengartikan bahwa kemampuan adalah kesanggupan, kecakapan, kekuatan kita berusaha dengan diri sendiri. Anggiat M. Sinaga dan Sri Hadiati (2001:34) mendefinisikan kemampuan sebagai suatu dasar seseorang yang dengan pelaksanaan pekerjaan secara efektif dan sangat berhasil.

Sementara itu, Robbin (2007:57) kemampuan berarti kepastian sesorang individu untuk melakukan beragam tugas dalam suatu pekerjaan. Lebih lanjut Robbin menyatakan bahwa kemampuan (ability) adalah sebuah penilaian terkini atas apa yang dapat dilakukan seseorang. Berdasarkan pengertian diatas dapat disimpulkan bahwa kemampuan (ability) adalah kecakapan atau potensi seseorang individu untuk menguasai keahlian dalam melakukan atau mengerjakan beragam tugas dalam suatu pekerjaan atau suatu penilaian atas tindakan seseorang, untuk melakukan beragam tugas dalam suatu pekerjaan. Keterbatasan kemampuan adalah keadaan dimana kita merasakan ketidakmampuan dalam melakukan sesuatu seperti kecakapan atau potensi seseorang individu untuk menguasai keahlian dalam melakukan atau mengerjakan beragam tugas dalam suatu pekerjaan atau suatu penilaian atas tindakan seseorang, untuk melakukan beragam tugas dalam suatu pekerjaan.

Kemampuan diartikan sebagai kapasitas individu ntuk mengerjakan berbagai tugas dalam pekerjaan tertentu. Kemampuan keseluruhan seseorang pada hakekatnya terdiri dari faktor kemampuan intelektual dan kemampuan fisik. Kemampuan intelektual adalah kapasitas untuk melakukan kegiatan-kegiatan mental. Sedangkan keampuan fisik diartikan sebagai kemampuan menjalankan tugas yang menuntut stamina, ketrampilan, kekuatan, dan karakteristik serupa. Kemampuan kerja akan akan menentukan kesiapan kerja. Kesiapan kerja adalah suatu keadan yang menunjukkan seseorang sudah siap sedia menggunakan tenaga atau kemampuannya dalam mengerjakan sesuatu baik sebagai karyawan maupun sebagai pencipta lapangan pekerjaan untuk memenuhi kebutuhan-kebutuhannya. Kemampuan dan kesiapan kerja seseorang dapat diimplementasikan di dalam sebuah pekerjaan. Persoalannya adalah ketersediaan lapangan kerja yang ada serta peluang untuk mendapatkan lapangan pekerjaan tersebut. Dengan semakin bertambahnya jumlah penduduk setiap tahunnya membuat banyaknya penduduk usia produktif untuk bekerja namun tidak semua penduduk yang berusia produktif mendapatkan pekerjaan, justru malah sebagian banyak yang menganggur dikarenakan lapangan pekerjaan yang kurang tersedia.

Keberadaan perusahaan perkebunan sawit, seharusnya memiliki dampak besar terhadap serapan tenaga kerja di daerah tempat perusahaan beroperasi. Selain itu perusahaan juga dapat menjadi 
tempat belajar atau latihan bekerja bagi para pekerja pemula yang belum berpengalaman. Masyarakat setempat juga mesti diberikan peluang seluasluasnya sesuai dengan kompetensinya untuk ikut serta bekerja sebagai karyawan. Banyak metode pengembangan karyawan yang dapat dilakukan oleh sebuah organisasi untuk meningkatkan kemampuan karyawan. Setiap organisasi bisnis besar pasti memiliki program pengembangan karyawan, yaitu dengan program pendidikan dan latihan. Menurut Undang-Undang SISDIKNAS Nomor 20 Tahun 2003 Bab 1, pasal 1. butir 1, mengatakan bahwa: Pendidikan adalah usaha sadar dan terencana untuk mewujudkan suasana belajar dan proses pembelajaran agar peserta didik secara aktif mengembangkan potensi dirinya untuk memiliki kekuatan spiritual keagamaan, pengendalian diri, kepribadian, kecerdasan, akhlak mulia, serta keterampilan yang diperlukan dirinya, masyarakat, bangsa dan negara. Peran serta masyarakat bersama pihak terkait dalam hal ini perusahaan dapat memperhatikan sektor pendidikan baik berupa sarana dan prasarana maupun memfasilitasi program pendidikan non formal di masyarakat. Peran serta perusahaan kepada masyarakat dalam berbagai bidang di masyarakat merupakan bagian dari program CSR (Corporate Social Responsibilty) setiap perusahaan. CRS mestinya harus dilaksanakan sesuai dengan peraturan yang berlaku sehingga merupakan kewajiban perusahaan untuk melakukannya. CSR merupakan bentuk pertanggungjawaban perusahaan. Tangungjawab tersebut muncul atas pertimbangan bahwa kegiatankegiatan perusahaan, khususnya yang berkaitan dengan eksploitasi Sumber Daya Alam (SDA), terkadang menimbulkan dampak psikologis yang buruk bagi masyarakat. Hal tersebut dapat juga menimbulkan berbagai konsekuensi, diantaranya adalah berubahnya struktur tatanan sosial ekonomi dan budaya masyarakat, kondisi fisik dan kerusakan lingkungan, serta beban psikologis dan trauma masyarakat sekitar.

Sebagai wujud tanggung jawab sosial perusahaan, maka perusahaan haruslah memberi manfaat pada masyarakat yang ada dilingkungan perusahaan. CSR merupakan suatu komitmen perusahaan yang dilaksanakan secara berkesinambungan untuk mewujudkan kesejahteraan sosial masyarakat. Pasal 1 ayat 3 Undang-Undang Nomor 40 Tahun 2017 tentang Perseroan Terbatas menyebutkan defenisi CSR adalah sebagai berikut : "Tanggung jawab Sosial dan Lingkungan adalah komitmen perseroan untuk berperan serta dalam pembangunan ekonomi berkelanjutan guna meningkatkan kualitas kehidupan dan lingkungan yang bermanfaat, baik bagi perseroan sendiri, komunitas setempat, maupun masyarakat pada umumnya." Selanjutnya Suharto (2009 : 105), mendefinisikan tanggugjawab perusahaan (CSR) sebagai : "kepedulian perusahaan yang menyisihkan sebagian keuntungannya bagi kepentingan pembangunan manusia dan lingkungan secara berkelanjutan berdasarkan prosedur yang tepat dan professional." Dengan demikian CRS berarti program sosial yang harus dilaksanakan oleh perusahaan yang berbadan hukum dan memenuhi kelayakan untuk beroperasi. Berdasarkan definsi diatas juga CRS dapat dijabarkan lebih lanjut, yaitu sebagai kewajiban perusahaan untuk memberikan kontribusinya ke berbagai stakeholder (pihak-pihak yang harus diberikan CRS) oleh perusahaan seperti memperhatikan kesejahteraan karyawan, penanam modal, masyarakat dan juga pemerintah.

Interaksi sosial yang terjadi berlangsung lama dan terus menerus pada akhirnya akan membentuk suatu corak hidup tersendiri dan menjadi ciri khas suatu kelompok masyarakat tertentu. Menurut (Koentjaraningrat, 2009: 153), "kebudayaan adalah keseluruhan sistem gagasan, tindakan dan hasil karya manusia dalam kehidupan masyarakat yang dijadikan milik diri manusia dengan belajar." Hal tersebut berarti bahwa hampir semua tindakan manusia itu adalah "kebudayaan" karena hanya sedikit kegiatan manusia yang tanpa belajar, hal itu disebut tindakan naluri, refleks, dan sebagainya. Kemampuan manusia dapat mengembangkan konsep-konsep yang ada dalam kebudayaan. Sebagai contoh dahulu makan dengan tangan sekarang semakin maju dan orang bisa membuat alat yaitu sendok sehingga dapat mengubah kehidupan seseorang menjadi lebih konsumtif dan bersih.

Selain itu juga ada nilai budaya yang terkandung dalam kebudayaan. Nilai budaya adalah tingkat yang paling tinggi dan paling abstrak dari adat-istiadat. Nilai budaya berfungsi juga sebagai pedoman hidup manusia dalam masyarakat, tetapi sebagai konsep, suatu nilai budaya itu bersifat sangat umum, mempunyai ruang lingkup yang sangat luas, dan biasanya sulit diterangkan secara rasional dan nyata. Namun, justru karena sifatnya yang umum, luas, dan tidak konkret, maka nilai-nilai budaya dalam suatu kebudayaan berada dalam daerah emosional dari alam jiwa para individu yang menjadi warga dan kebudayaan yang bersangkutan. Kebudayaan memiliki beberapa unsur yang dapat mempengaruhi kualitas hidup individu, baik kualitas dari segi hal-hal fisik seperti kemajuan dalam hal pengetahuan, kepemilikan harta benda maupun kualitas spiritualitas. Menurut Koentjaraningrat ( 2009: 164-165), unsur-unsur kebudayaan terdiri Bahasa, Sistem pengetahuan, Organisasi social, Sistem peralatan hidup dan teknologi, S is te m mata pencaharian hidup, Sistem religi, Kesenian

Bahasa akan membentuk sebuah identitas pada masyarakat, dengan bahasa manusia dapat mengekspresikan perasaan dan keinginannya pada orang lain. Khususnya bahasa daerah, bahasa memiliki dialek atau gaya bahasa tersendiri dan bunyi bahasa serta perbedaan kata-kata di dalam 
pengungkapan sebuah maksud. Oleh karena itu bahasa daerah dikenal dengan istilah bahasa ibu. Bahasa-bahasa yang ada dapat mengalami pergeseran kosakata dan bunyi bahasa yang bisa disebabkan oleh arus modernisasi dan pengaruh budaya asing. Unsur budaya berikutnya adalah sistem pengetahuan. Antara daerah yang satu dengan daerah yang lain dapat memiliki sistem pengetahuan yang berbeda, misal dalam hal bercocok tanam, acara-acara ritual dan peraturan-peraturan yang berupa hukum adat. Keaslian budaya atau adat istiadat tersebut dapat terjaga apabila generasi muda secara bersama-sama melestarikannya. Namun ada kecendrungan sedikit demi sedikit adat budaya yang ada sejak turun temurun mulai terkikis karena modernisasi dan perkembangan jaman. Banyak pula generasi muda yang tidak peduli dan meneruskan adat istiadat yang ada. Pudarnya adat istiadat yang ada dapat juga dipengaruhi oleh budaya luar yang dibawa oleh orang asing ke daerah setempat. Perubahan yang dibawa oleh orang luar kesuatu wilayah tidak selalu berdampak negatif, namun dapat pula memberi perusahaan kearah yang lebih baik. Misalnya pola kerja yang efektif dan efisien yang dicontohkan oleh yang asing yang datang.

Seiring perkembangan jaman, teknologi pun semakin lama semakin luas. Karena makin banyaknya masyarakat yang hidup modern. Kehadiran teknologi sangat diperlukan untuk meningkatkan peradaban manusia. Namun demikian, teknologi akan menimbulkan dampak lain, yaitu dampak negatif. Dapat saja berkaitan dengan budaya teknologi akan disalahgunakan sehingga akan dapat bertentangan norma-norma yang berlaku. sekarang banyak yang menyalahgunakan alat teknologi khususnya internet. Tidak sedikit masyarakat yang tertipu atau melakukan perbuatan asusila dengan internet. Mata pencaharian sangat diperlukan untuk setiap masyarakat karena bermanfaat untuk memenuhi kehidupan manusia. Misalnya profesi sebagai pegawai/karyawan, petani, nelayan, dan sebagainya. Contohnya masyarakat yang hidup dipesisir pantai lebih banyak bermata pencaharian sebagai nelayan atau masyarakat yang hidup diperkotaan lebih banyak bermata pencaharian sebagai pegawai kantoran. Sistem dan Organisasi kemasyarakatan dapat dimiliki masyarakat berbeda-beda pada setiap masyarakat. Sistem ini akan membentuk suatu karakteristik tersendiri yang dapat mempengaruhi corak kehidupan, dan tata pergaulan pada masyarakat. Dengan sistem dan organisasi kemasyarkatan ini, manusia saling berinteraksi membentuk suatu komunitas, sehingga segala cipta, karsa, dan rasa dapat teraktualisasi di dalam komunitas tersebut. Dengan demikian individu dapat mengembangkan potensi dan jati dirinya di dalam kelompok dan di dalam masyarakat yang lebih luas.
Sebagai bangsa yang majemuk, bangsa Indonesia mempunyai sistem religi atau agama dan kepercayaan yang bermacam-macam. Oleh karena itu terkadang suatu suatu kelompok atau masyarakat tertentu menganut paham atau kepercayaan yang mayoritas. Misalnya masyarakat Bali yang secara mayoritas beragama Hindu. Kemudian agama islam mayoritas dibeberapa daerah di pulau Jawa, Kristen di Papua, dan sebagainya. Setiap agama memiliki tata cara dan kebiasaan yang harus dipatuhi oleh semua pemeluknya. Sementara yang pemeluk agama lain harus menghormati dan menjaga keharmonisan antara sesama di dalam kesatuan masyarakat tersebut. Unsur budaya selanjutnya adalah kesenian. Setiap daerah memiliki ciri khas kesenian masing-masing, sehingga dikenal berbagai seni tari, lagu daerah dan bentuk-bentuk kreasi kesenian lainnya. Antara daerah yang satu dengan yang lainnya memiliki kesenian dan corak masing-masing yang merupakan nilai leluhur bangsa dan sebagai identitas suatu daerah. Nilai seni dan budaya tersebut mesti dilestarikan agar tetap ada dari generasi ke generasi. Namun adat dan seni budaya tersebut acapkali dapat terkikis dan tergerus oleh jaman. Eksistensi seni dan budaya dapat terancam oleh karena kurangnya kepedulian generasi muda untuk melestarikannya, selainnya mulai memudarnya keaslian adat budaya tersebut dapat dipengaruhi oleh trend dan gaya hidup masa kita yang lebih egoistis dan konsumerisme. Pengaruh tersebut dapat datang dari luar. Seseorang atau sekelompok orang yang datang, baik untuk menetap sebagai warga suatu desa maupun yang tinggal sementara dapat membawa adat, cara hidupnya dari daerah asal. Cara hidup dan kebiasaan tersebut sedikit banyak dapat mempengaruhi penduduk dimana individu tersebut tinggal.

Ekonomi berarti aktivitas manusia yang berkaitan dengan upaya pengolahan barang dan jasa untuk menghasilkan nilai serta transaksi (jual beli barang dan jasa tersebut antar sesama yang saling memerlukan). Nilai barang dan jasa tersebut diukur dengan satuan moneter suatu bangsa, yaitu mata uang sebagai alat pembayaran yang sah. Oleh karena itu di dalam konsep ekonomi dikenal istilah pendapatan, biaya, proses produksi, dan pemasaran. Tinjauan secara makro ekonomi, konsep ekonomi lebih luas, tidak hanya berbicara ekonomi rumah tangga atau perusahan saja. Namun lebih dari itu karena berkaitan dengan kondisi ekonomi secara keseluruhan. Banyak pihak yang terlibat di dalam ekonomi mulai dari pemerintah, perbankan, elitelit politik, pertahanan keamanan dan pelaku ekonomi itu sendiri, yaitu perusahaan dan individuindividu yang bergerak dalam bidang kewirausahaan serta para pegawai atau karyawan sebuah organisasi baik organisasi publik maupun organisasi swasta (pebisnis). beberapa konsep penting di dalam mengkaji aspek ekonomi diantaranya adalah 
distribusi pendapatan, kesempatan kerja, dan tingkat kemiskinan.

Distribusi pendapatan adalah penyerapan atau penyebaran pendapatan yang diterima oleh masyarakat. Distribusi pendapat dapat diterima dengan jumlah yang berbeda-beda. Hal ini bisa terjadi akibat perbedaan produktivitas yang dimiliki oleh setiap individu dimana satu individu/kelompok mempunyai produktivitas yang lebih tinggi dibandingkan dengan individu/kelompok lain, sehingga ketimpangan distribusi. pendapatan tidak hanya terjadi di Indonesia saja tetapi juga terjadi di beberapa Negara di dunia. Menurut Setianegara (2008:88) "masyarakat yang berbeda mempunyai persepsi yang berbeda pula tentang apa itu adil (merata) dan norma-norma sosial budaya, sehingga kebijakan yang dilakukan untuk meningkatkan pemerataan tetap saja menimbulkan konsensus bahwa terjadi ketidakmerataan yang cukup besar dalam hal distribusi pendapatan." Berdasarkan pendapat diatas dapat diuraikan bahwa setiap daerah memahami distribusi pendapatan dalam kontek yang berbeda.

Pada daerah perkebunan kelapa sawit misalnya, masyarakat memandang distribusi pendapatan ini dilihat dari proporsi yang dapat perusahaan berikan kepada masyarakat melalui individu-individu yang terlibat dengan pihak perusahaan, misal mereka yang menjadi pegawai/ karyawan perusahaan, dan bagi mereka yang memiliki lahan plasma yang dikelola oleh perusahaan. Oleh karena itu distribusi pendapatan dari perspektif masyarakat adalah bagaimana prilaku adil yang dilakukan oleh yang berkuasa baik itu pemerintah maupun pihak swasta. Menurut Hariadi (2007:4), "Semakin tinggi pertumbuhan Produk Domestik Bruto (PDB) atau semakin besar pendapatan per kapita semakin besar perbedaaan antara kaum miskin dan kaum kaya. Pertumbuhan GNP per kapita yang cepat tidak secara otomatis meningkatkan tingkat hidup rakyat banyak." Ketimpangan pendapatan menjadi permasalah dalam besarnya pemerataan pendapatan suatu daerah, banyak kendala yang dihadapi untuk mengatasi ketidakmerataan tersebut. ketimpangan yang terjadi antara si miskin dan si kaya sangat besar. Misalnya ketimpangan yang terjadi pada petani, petani yang memiliki lahan yang luas akan lebih maksimal memperoleh pendapatan per kapita, sedangkan petani yang memiliki lahan sempit merekapun sudah mengelola lahannya sedemikian rupa namun hasilnya tetap minim, apalagi para buruh yang tidak mempunyai lahan mereka hanya pasrah mengandalkan gaji dari para petani besar. Selain itu para petani kecil tersebut tidak memiliki keahlian atau pendidikan yang tinggi sehingga mereka tidak bisa bekerja disektor non pertanian.

Tondaro dan Smith, (2006:234) "menyatakan bahwa ada dua ukuran di dalam distribusi pendapatan, yang pertama, distribusi pendapatan perseorangan, (personal distribution of income) dan distribusi pendapatan fungsional." Distribusi pendapatan perseorangan (personal distribution of income) atau distribusi ukuran pendapatan (size distribution of income) ini merupakan ukuran yang paling sering digunakan oleh para ekonom untuk mengukur/menghitung secara langsung jumlah penghasilan yang diterima oleh setiap individu atau rumah tangga. Sementara distribusi pendapatan fungsional atau pangsa distribusi pendapatan per faktor produksi ( functional or factor share distribution of income) menurut Tondaro dan Smith (2006:240) "adalah mengukur pendapatan dari pendapatan nasional total yang diterima oleh masing-masing faktor produksi (tanah, tenaga kerja, dan modal)."

Teori distribusi pendapatan fungsional ini pada dasarnya mempersoalkan persentase penghasilan tenaga kerja secara keseluruhan, bukan sebagai unit-unit usaha atau faktor produksi yang terpisah secara individual, dan membandingkannya dengan persentase pendapatan total yang dibagikan dalam bentuk sewa, bunga, dan laba (masingmasing merupakan perolehan dari tanah, modal, uang, dan modal fisik). Kemiskinan dalam arti sempit merupakan suatu keadaan dimana masyarakat yang mengalaminya kekurangan dalam hal sandang, pangan, dan papan. Kekurangan ini terjadi jangka waktu lama dan terus menerus. Setiap negera atau wilayah akan memiliki batasan tertentu yang tidak sama antara satu daerah dengan daerah yang lain. Hal ini karena tingkat pertumbuhan ekonomi suatu daerah berbeda, sehingga pemerintah memiliki batasan tertentu yang disebut masyarakat miskin. Menurut kamus bahasa Indonesia, arti miskin adalah tidak berharta, serba kekurangan berpenghasilan sangat rendah). Oleh karena kemiskinan sangat relatif, dan hanya dapat dijelaskan secara kualitatif karena belum ada standar yang jelas.

Menurut Adit (2010 : 18), "kemiskinan adalah sebagai keadaan kekurangan uang dan barang untuk menjamin kelangsungan hidup.” Lebih lanjut Adit (2010 : 18) menjelaskan dalam arti luas, mengatakan bahwa kemiskinan adalah suatu intergrated concept yang memiliki lima dimensi, yaitu: Kemiskinan (proper), Ketidakberdayaan (powerless), Kerentanan menghadapi situasi darurat (state of emergency), Ketergantungan (dependence), Keterasingan (isolation) baik secara geografis maupun sosiologis

Definisi kemiskinan menurut Cahyat (2010 : 2), "kemiskinan adalah suatu situasi di mana seseorang atau rumah tangga mengalami kesulitan untuk memenuhi kebutuhan dasar, sementara lingkungan pendukungnya kurang memberikan peluang untuk meningkatkan kesejahteraan secara berkesinambungan atau untuk keluar dari kerentanan." Berdasarkan pendapat para ahli diatas kemiskinan dapat diartikan dalam arti sempit 
maupun dalam arti luas. Kemiskinan dalam arti sempit adalah suatu kondisi tidak berpunya dan atau minim materil berupa kebutuhan akan makanan, pakaian, dan perumahan. Sementara kemiskinan dalam arti luas dapat mencakup kemiskinan dalam hal material, sosial, dan spiritual. Kemiskinan pada masyarakat dapat timbul dikarenakan oleh berbagai macam sebab, baik yang berasal dari dalam diri sendiri maupun dari luar individu. Kemiskinan yang berasal dari dalam diri akibat lemahnya pengetahuan, keterampilan, serta sikap yang kurang mendukung. Manajemen yang salah terhadap pengelolaan pekerjaan dan pengelolaan sumber daya yang ada merupakan salah satu penyebab kemiskinan yang berasal dari dalam diri individu. Sementara disisi lain faktor dari luar, dapat saja terjadi misalnya program pemerintah yang kurang menyentuh untuk pembangunan di pedesaan. Eksploitasi sumber daya alam dari pihak pemerintah maupun swasta juga turut serta memiskinkan masyarakat. Perampasan tanah oleh perusahaan melalui dukungan pemerintah memberikan ijin operasi perusahaan di suatu wilayah misalnya dapat saja menyebabkan masyarakat kehilangan tanah (lahan) yang selama ini dikelola untuk perumahan, maupun untuk perkebunan individual.

Indikator ekonomi dapat juga dilihat dari kondisi masyarakat dalam hal kesehatan dan sanitasi lingkungan. Masyarakat yang mampu secara ekonomi pasti ada korelasinya dengan kemampuannya di dalam bidang kesehatan. Mengingat kesehatan memerlukan biaya. Untuk melihat seberapa baik tingkat kesehatan masyarakat dapat diketahui juga seberapa banyak dan layaknya fasilitas kesehatan yang ada di masyarakat seperti pusat kesehatan desa (Puskesdes), Posyandu (Pos Pelayanan Terpadu) dan lain sebagainya. Secara teoritis, kesehatan menurut Santoso (2012: 8) "adalah keadaan seimbang yang dinamis, dipengaruhi faktor genetik, lingkungan dan pola hidup sehari-hari seperti makan, minum, seks, kerja, istirahat, hingga pengelolaan kehidupan emosional." Kemudian Undang-Undang Republik Indonesia nomor 23 tahun 1992 menyatakan bahwa "Kesehatan adalah keadaan sejahtera dari badan, jiwa dan sosial yang memungkinkan setiap orang hidup produktif secara social dan ekonomi." Kesehatan merupakan salah satu faktor utama yang dapat mempengaruhi kebugaran dan penampilan tubuh, serta harta yang paling berharga yang tidak pernah bisa ditukar dengan apapun. Oleh karena itu setiap orang tentu mendambakan hidup sehat bahagia dan ingin selalu tampak sehat, bugar, penampilan yang bagus dan awet muda, tidak lekas keriput karena menua. Hal tersebut dapat dirasakan apabila kita pernah sakit. Olahraga dan kesehatan merupakan kebutuhan bagi setiap orang, karena semua orang pasti ingin sehat, tidak seorangpun yang ingin sakit atau terganggu kesehatannya.
Kajian lain mengenai kesehatannya dapat juga ditinjau dari aspek sosial. Pada bidang sosial adalah dapat diketahui dari seberapa besar pengaruh dari aktvitas masyarakat dan perusahaan yang dapat menimbulkan dampak kesehatan karena pencemaran lingkungan, seperti pencemaran air, tanah, dan udara. Pencemaran akibat dampak dari aktivitas perusahaan sangat mempengaruhi kualitas air, udara, tanah apabila perusahaan tidak mematuhi kaidah-kaidah dalam Analisis Dampak Lingkungan (AMDAL).

\section{METODE PENELITIAN}

Penelitian ini merupakan jenis penelitian deskriptif, Seperti yang dikemukakan oleh Sugiyono (2011 : 15) "penelitian desktiptif adalah sebuah penelitian yang bertujuan untuk memberikan atau menjabarkan suatu keadaan atau fenomena yang terjadi saat ini dengan menggunakan prosedur ilmiah untuk menjawab masalah secara aktual". Sedangkan, Sukmadinata (2006: 89) menyatakan bahwa metode penelitian deskriptif adalah sebuah metode yang berusaha mendeskripsikan, menginterpretasikan sesuatu, misalnya kondisi atau hubungan yang ada, pendapat yang berkembang, proses yang sedang berlangsung, akibat atau efek yang terjadi atau tentang kecenderungan yang sedang berlangsung. Subjek penelitian di dalam penelitian ini adalah General Manager, Manager Community Development dan Lingkungan, Kepala Desa Agromulyo, Tokoh masyarakat.

Pengumpulan data melalui Pengamatan/ Observasi: Wawancara atau interview dan Studi Dokumentasi. Dengan teknik analisis yang digunakan dalam penelitian ini adalah analisis kualitatif.

Analisis data kualitatif terdiri dari tiga alur kegiatan yang terjadi secara bersamaan yaitu: reduksi data, penyajian data dan penarikan kesimpulan/ verifikasi. Lokasi penelitian terletak di Desa Agromulyo Kecamatan Ketungau Tengah Kabupaten Sintang.

\section{HASIL PENELITIAN DAN PEMBAHASAN}

PT. Perdana Sawit Plantation (PSP) beroperasi di wilayah kecamatan Ketungau tengah dan salah satu desa yang masuk wilayah perkebunan adalah desa Agromulyo. PT. PSP di kecamatan ketungau tengah merupakan kantor kebun, sementara kantor pusatnya berada di Jakarta, tepatnya di Komplek Perkantoran Duta Merlin Blok C Nomor 56 - 57 Jalan Gajah Mada. Untuk alamat kantor PSP di Kecamatan Ketungau tengah dengan wilayah operasinya meliputi kecamatan ketungau tengah dan ketungau hilir. Sebagai sebuah perusahaan yang berbentuk Perseroan Terbatas (PT), PSP memiliki badan hukum usaha, yaitu badan hukum nomor AHU-0059887_AH01.09 berdiri pada tanggal 17 Juli 2008. Luas perkebunan 
17.700 Hektar (Ha). Dengan rincian luas perkebunan plasma 2.251,48 Ha dan luas kebun inti 15.448,52 Ha. Jumlah pemilik kebun plasma sebanyak 968 orang dari 10 desa dan 19 dusun yang tersebar di kecamatan ketungau hilir dan kecamatan ketungau tengah. PT. Perdana Sawit Plantation sebagai perusahaan yang bergerak dibidang perkebunan secara hukum telah mengantongi ijin usaha dari pemerintah. Khususnya untuk wilayah Kalimantan Barat sudah mendapat pengesahan akta pendirian dan memiliki dokumendokumen pendukung sebagai syarat pendirian perusahan berbentuk Perseroan Terbatas (PT).

Secara administratif wilayah kebun kelapa sawit PT. Perdana Sawit Plantation-Argomulyo Estate termasuk dalam wilayah Desa Argo mulyo, Desa Panggi Agung, Desa Landau Buaya, Desa Beloh Mulyo, Desa Betung Permai, Desa Nanga Merkak, Desa Senibung, Desa Bukit Sidin Permai dan Desa Deras. Desa-desa tersebut masuk dalam wilayah kecamatan Ketungau Tengah dan Kecamatan Ketungau Hilir.PT. Perdana Sawit Plantation Agro Mulyo Estate dapat ditempuh melalui jalur jalan darat maupun jalur sungai. Melalui jalan darat dapat dilalui dengan menggunakan kendaraan baik roda dua maupun roda empat dengan jarak tempuh $92 \mathrm{Km}$ dari Kota Kabupaten Sintang, sementara bila menggunakan jalur sungai dengan jarak $159 \mathrm{~km}$ dengan waktu tempuh kurang lebih 2,5 jam menggunakan speed boat.

Keberadaan perusahaan selalu memberikan suatu dampak, baik dampak positif maupun dampak negatif. Hal tersebut sudah menjadi sebuah konsekuensi setiap operasional kegiatan. Para pengagas proyek memperhitungkan yang ideal yaitu memperhitungkan berbagai aspek dengan matang studi kelayakan proyek sebelum, sedang proses maupun ketika sebuah proyek selesai beroperasi. Tidak mudah dan hampir tidak ada yang mampu menghindari kekurangan-kekurangan dari aspek yang ada. Banyak aspek yang harus dikaji sebetulnya di dalam mengkaji sebuah proyek berkaitan dengan kelayakan usaha. Pada intinya adalah sebuah peroyek sebagaimana perusahaan perkebunan kelapa sawit harus menyeimbangkan antara kepentingan internal perusahaan dan kepentingan eksternal, yaitu kepentingan masyarakat, pemerintah dan lingkungan hidup.Konsekuensi dari pemenuhan aspek sosial maka perusahaan harus mengalokasi dana khusus untuk memenuhi kebutuhan-kebutuhan sosial, sehingga perusahaan harus mengeluarkan biaya sosial (sosial cost). Termasuk juga biaya-biaya yang tidak diperuntukan untuk operasional adalah biaya untuk pengelolaan lingkungan hidup. Pada aspek sosial ini masyarakat harus dapat menikmati manfaat yang berupa sarana dan prasarana umum yang dapat dipergunakan masyarakat secara umum, seperti jalan raya, perubahan pola kerja, penyerapan tenaga kerja masyarakat lokal, peningkatan kualitas hidup dibidang kesehatan, dan pendidikan.

\section{Aspek Sosial}

Penelitian mengenai aspek sosial pada PT. Perdana Sawit Plantation diperoleh informasi dan data keterlibatan perusahaan di dalam memberikan kontribusi yang dapat memberikan manfaat kepada masyarakat. Perusahaan di dalam menjalankan operasinya tentu berpatokan pada ketentuan yang ada di perusahaan. Berdasarkan hasil penelitian diperoleh data mengenai kegiatan perusahaan yang berkaitan dengan ruang lingkup sosial, yaitu kegiatan yang terkait dengan program Corporate Social Responsibility (CSR) sebagai bentu rasa tanggung jawab perusahaan terhadap masyarakat di sekitar perusahaan. Program tersebut bertujuan untuk meningkatkan kesejahteraan masyarakat sekitar, dengan melakukan pembangunan atau perbaikan infrastruktur dan menjaga lingkungan. CSR dapat berupa kegiatan sosial, budaya, Ekonomi masyarakat, pendidikan, kesehatan, keagamaan, dan adat istiadat. Untuk pembangunan di desa dilakukan pembangunan berupa fasilitas umum di desa. Terdapat 5 (lima) pilar yang mencakup kegiatan CSR yaitu : 1. Pengembangan kapasitas Sumber Daya Manusia (SDM) di lingkungan internal perusahaan maupun lingkungan masyarakat sekitarnya. Penguatan ekonomi masyarakat sekitar kawasan wilayah kerja perusahaan. Pemeliharaan hubungan relasional antara korporasi dan lingkungan sosial kemasyarakatan. Perbaikan tata kelola perusahaan yang baik. Pelestarian lingkungan, baik lingkungan fisik, sosial serta budaya.

Adapun manfaat yang diperoleh dari program CSR bagi karyawan dan masyarakat adalah sebagai berikut: Meningkatnya kesejahteraan karyawan dan masyarakat sekitar sehingga tercipta kemandirian masyarakat baik secara ekonomi maupun tatanan sosial. Adanya peningkatan kualitas SDM karyawan dan masyarakat sekitar kebun. Meningkatnya pemeliharaan fasilitas umum. Adanya pembangunan fasilitas karyawan dan desa masyarakat yang bersifat sosial dan keagamaan sehingga berguna untuk masyarakat yang berada di sekitar perusahaan tersebut berada. Ruang lingkup program CSR mencakup aspek yang cukup luas, bukan hanya terbatas pada pembangunan sarana dan prasrana di masyarakat saja, tetapi mecakup semua stakeholder yang terkait. Stakeholder atau pihak-pihak terkait secara garis besar dapat dikelompokan menjadi dua yaitu, stakeholder internal dan ekternal perusahaan. Stakeholder internal meliputi pemilik perusahaan, penanam saham atau para investor, dan para pegawai yang ada di perusahaan. Menurut general Manager, bahwa semua pihak yang ada di internal perusahaan harus mendapat perlakuan yang adil dari perusahaan, yang tentunya berkaitan dengan 
kewajiban perusahaan untuk memenuhi hak mereka secara proporsional.

Oleh karena itu program CSR mencakup hal yang luas, yang bukan saja aspek hanya aspek sosial, budaya, pendidikan, kesehatan, gaya hidup tetapi juga hampir semua aspek termasuk ekonomi di dalamnya. Kontribusi atau kewajiban perusahaan terhadap pemilik adalah memberikan laba atau keuntungan dari kegiatan perusahaan yang besarnya harus sesuai dengan ketentuan yang tercantum pada Anggaran Dasar (AD) dan Anggaran Rumah Tangga (ART) perusahaan. Begitu pula tanggung jawab perusahaan kepada para tim manajemen atau pegawai perusahaan, tanggung jawabnya adalah memberikan kompensasi berupa gaji yang disesuaikan dengan jabatan, masa kerja, bagian pekerjaan, serta prestasi kerja pegawai. Ketentuan mengenai penggajian diatur di dalam peraturan kepegawaian yang dikelola oleh bagian kepegawaian perusahaan. Perusahaan di dalam memberikan gaji kepada pegawai tentunya menyesuaikan kemampuan perusahaan untuk memberikan gaji serta masih di dalam koridor yang tidak melanggar peraturan pemerintah. Oleh karena itu standar penggajian untuk gaji terendah tidak boleh rendah dari ketetapan Upah Minimum Kabupaten Sintang, upah tersebut mengacu kepada peraturan pemerintah pada wilayah operasi perusahaan yaitu wilayah kecamatan Ketungau Tengah dan Ketungau Hilir sebagai kecamatan yang berada pada wilayah pemerintah daerah Kabupaten Sintang. Ketetapan gaji tersebut berlaku untuk pegawai yang sudah diangkat sebagai karyawan tetap perusahaan. Lain hal dengan gaji untuk buruh harian lepas dimana perhitungannya berdasarkan hitungan Hari Kerja.

Selain gaji, kompensasi yang diberikan oleh perusahaan sebagai bentuk tanggung jawab perusahaan adalah pemberian insentif dan tunjangan kepada para pegawai. Insentif dapat diberikan kepada karyawan yang bekerja lebih dari waktu kerja yang seharusnya, misalnya pemberian kepada karyawan yang bekerja lembur. Kemudian pemberian tunjangan-tunjangan seperti tunjangan jabatan, tunjangan keluarga, dan tunjangan hari raya keagamaan. Tanggung jawab lainnya adalah dengan pemberian jaminan perlindungan keamanan kerja bagi karyawan.

Sementara untuk stakeholder eksternal yaitu masyarakat, pemerintah, dan lembagalembaga yang lain seperti lembaga keuangan, LSM dan sebagainya. Pihak-pihak tersebut juga harus diperhatikan oleh pihak perusahaan berkaitan dengan kewajiban perusahaan sebagai bagian dari masyarakat secara yang ada di dalam wilayah dalam cakupan yang lebih luas. Tanggung jawab sosial perusahaan untuk masyarakat perusahaan telah berkontribusi memberikan sarana dan prasarana yaitu berupa pembangunan jalan raya yang menghubungan desa-desa yang sebelumnya terisolir menjadi desa yang mudah melakukan akses keluar dengan adanya jalan raya yang dibuat oleh perusahaan sehingga dengan adanya jalan tersebut masyarakat semakin lebih mudah melakukan perjalanan baik menuju ke kota kecamatan maupunakses menuju kota kabupaten sintang. Dengan adanya jalan tersebut, pembangunan dan perkembangan di masyarakat dapat lebih cepat baik dari sektor ekonomi, pendidikan dan kesehatan.

Sementara untuk tanggung jawab ke pemerintah, perusahaan telah memenuhi semua persyaratan hukum yang ditetapkan oleh pemerintah. Perusahaan telah melengkapi semua persyaratan hukum berupa pengurusan dokumendokumen termasuk juga mengurus kelayakan proyek dari aspek lingkungan dengan melakukan Analisis Dampak Lingkungan (AMDAL). Perusahaan dari aspek yuridis telah melengkapi semua persyaratan yang telah ditetapkan pemerintah sehingga di dalam pelaksanaan operasinya telah layak secara hukum. Kemudian kepada pihak lembaga lainnya, perusahaan juga menjalin kerja sama dengan pihak perbankan dalam hal pendanaan proyek sebagai sumber untuk mendapatkan permodalan. Kerja sama tersebut tertuang dalam bentuk perjanjian kerja sama yaitu dalam hal perkreditan. Kerja sama tersebut juga memiliki konsekuensi bagi perusahaan untuk melaksanakan kewajibannya, yaitu menggembalikan pokok kredit dan balas jasa yang ketentuannya diatur di dalam peraturan kerjasama tersebut dan mengacu pada peraturan perbankan.

Aspek sosial yang dilakukan oleh perusahaan diantaranya adalah mengenai kebijakan rekrutmen tenaga kerja untuk menjadi karyawan atau pegawai di perusahaan PT. Perdana Sawit Plantation, sebenarnya perusahaan berusaha untuk merekrut lebih banyak sumber tenaga kerja dari masyarakat di wilayah kerja perusahaan, namun masih terkendala persyaratan yang dapat dipenuhi oleh masyarakat dalam hal kompetensi yang dimiliki, sehingga tidak banyak komposisi penduduk yang dapat diterima sesuai syarat yang ditentukan. Berdasarkan data yang ada, komposisi tenaga kerja yang berasal dari desa masyarakat sekitar berkisar antara $30 \%$ - $40 \%$ saja. Penyerapan tenaga kerja yang bersumber dari masyarakat yang masih rendah tersebut selain faktor kompetensi juga dipengaruhi oleh faktor lain yaitu minat masyarakat untuk menjadi pegawai yang masih rendah.

Serapan tenaga kerja pada penduduk sekitar lebih banyak pada level pada bagian buruh harian lepas. Untuk tenaga kerja pegawai masih sedikit yang berasal dari masyarakat lokal. Pegawai untuk bagian yang memegang suatu jabatan lebih banyak 
bersumber dari tenaga kerja dari luar Kalimantan, yaitu dari sumatera dan jawa. Terutama untuk tenaga-tenaga ahli yang lulusan sarjana rata-rata berasal dari luar daerah, seperti para manager, Asisten kepala, dan asisten baik untuk bagian kantor maupun bagian lapangan. Hubungan antara perusahaan dengan masyarakat selama ini tergolong cukup baik dan tidak pernah terjadi konflik sebagaimana seperti yang terjadi di daerah-daerah lain. Namun tetap saja ada beberapa masyarakat yang tidak puas dengan kehadiran perusahaan. Ketidakpuasan tersebut wajar karena berkaitan dengan kepentingannya yang tidak dipenuhi oleh perusahaan. Menurut kepala desa secara langung tidak ada dampak sosial yang ditimbulkan oleh perusahaan belum terlalu dapat disimpulkan disimpulkan secara pasti apakah karena kehadiran perusahaan atau karena perubahanan jaman. Pada jaman sekarang Nampak terjadi pergeseran sosial, misalnya mulai berkurangnya semangat gotong royong masyarakat dibanding pada 10 atau 20 tahun yang lalu. Kemudian gaya hidup, terutama anakanak muda sekarang yang lebih banyak meniru gaya-gaya orang perkotaan, baik dari cara berbicara, pola makan, berpakaian, dan cara pergaulan.

Pergeseran pola sosial tersebut diatas, beberapa yang dapat memberikan dampak positif dan ada juga perubahan yang berupa dampak negatif, misalnya mulai lunturnya semangat rotong royong, pola makan yang ingin makan instan, kebiasaan beberapa masyarakat yang kurang bermanfaat, misalnya masih ada sekelompok masyarakat yang menghabiskan uangnya untuk membeli minum-minuman keras dan juga perjudian. Hal-hal tersebut merupakan masalah sosial yang tentunya merugikan masyarakat, walaupun tidak semua masyarakat terkena masalah tersebut. Namun yang dapat dilihat dari hal-hal positif yang dilakukan oleh perusahaan adalah dukungan yang diberikan kepada masyarakat terutama dukungan materil untuk berbagai fasilitas untuk masyarakat. Perusahaan juga selalu ikut berpartisipasi di dalam kegiatan-kegiatan adat- istiadat desa, misalnya ikut di dalam kegiatan gawai dayak yang diselenggarakan oleh desa. Menurut kepala desa ada beberapa adat dan budaya yang masih dapat dilestarikan sampai sekarang antara lain gawai dayak sebagai ungkapan rasa syukur setelah panen padi, kemudian adat matah bunga, ngelak begentu, dan ngetas ranyai. Adat dan budaya tersebut tetap lestari dan diadakan secara berkala oleh masyarakat dan didukung penuh oleh pihak perusahaan.

Sepak terjang perusahaan dilihat masyarakat tentu tidak terlepas dari berbagai kepentingan. Pihak perusahaan tentunya menginginkan perusahaannya berkembang sehingga menguntungkan khususnya bagi pemilik dan investor. Sedangkan disisi lain perusahaan juga harus berbuat hal-hal yang positif untuk orang lain diluar perusahaan terutama pada masyarakat sekitar. Persoalan yang terjadi dengan adanya perusahaan pada awalnya tentu ada pro dan kontra dengan adanya perusahaan masuk. Persoalannya adalah terutama pada masalah pembebasan tanah masyarakat yang dimasuki oleh perusahaan untuk lokasi perkebunan, namun sekarang persoalan tersebut sudah dapat diatasi dengan komunikasi dan mediasi yang baik antara perusahaan dengan masyarakat yang dalam hal ini di mediasi oleh pemerintah desa. Hal-hal positif yang dirasakan oleh masyarakat tentunya adalah sarana dan prasarana yang diberikan oleh perusahaan seperti jalan raya walaupun masih jalan tanah namun ada beberapa ruas jalan yang sudah pengerasan oleh perusahaan sehingga cukup lancar untuk dilalui dengan menggunakan kendaraan baik sepeda motor maupun kendaraan roda empat. Perusahaan juga berpartisipasi pada kegiatan pada acara 17 Agustus dalam rangka memperingati hari kemerdekaan Republik Indonesia.

Perusahaan memberikan beberapa fasilitas seperti memberikan sumbangan beberapa alat olah raga kepada kelompok pemuda di masyarakat, serta juga megundang masyarakat untuk melaksanakan perlombaan-perlombaaan bersama untuk memeriahkan pelaksanaan acara 17 Agustus. Berkaitan dengan sosial budaya selain perusahaan berpartisipasi dalam bentuk barang, perusahaan juga berpartisipasi juga dalam bentuk uang, yaitu dalam bentuk sumbangan untuk acara-acara pesta HUT RI dan juga acara-acara adat yang di selenggarakan oleh desa. Selain dampak-dampak positif yang sangat bermanfaat bagi masyarakat tentu ada beberapa hal yang dianggap kurang baik efek yang ditimbulkan dari kehadiran perusahaan, yaitu kebiasaan masyarakat melakukan permainan di barak-barak di perusahaan, terutama setelah selesai gajian, permainan tersebut seperti remi box dan gaplek namun peneliti belum mendapatkan data apakah permainan tersebut dalam kategori perjudian atau hanya permainan biasa.

Sebagian besar pegawai yang bekerja di perusahaan adalah orang dari luar desa argo mulyo atau desa sekitar. Kemudian porsi tenaga kerja yang berasal dari masyarakat sekitar lebih banyak yang menjadi buruh harian lepas dengan pekerjaannya adalah sebagai tenaga kerja bagian penanaman, pemeliharaan, dan pemanenan buah kelapa sawit, namun demikian tenaga kerja dari luar pun masih cukup banyak yang didatangkan dari luar untuk pekerja sebagai buruh tersebut. Kehadiran perusahaan berdampak pada kebiasaan masyarakat yang dulunya mudah untuk mendapatkan lauk pauk dengan berburu binatang dihutan, sekarang sudah langka karena hutan tempat hidup binatang seperti babi, rusa, kijang, burung dan sebagainya tidak ada 
lagi, sehingga sekarang masyarakat kesulitan untuk mendapatkan makanan dari hasil hutan. Selanjutnya kegiatan berladang sebagai bagian dari aktivitas sosial masyarakat sekarang juga sulit dilakukan karena hutan sudah mulai berkurang akibat hamparan yang dulunya hutan sekarang sudah berubah menjadi hamparan perkebunan kelapa sawit sejauh mata memandang. Disisi lain peneliti juga melihat bahwa masyarakat juga diuntungkan karena dengan adanya jalan perusahaan yang dibangun masyarakat banyak yang lebih maju baik dari segi perekonomiannya maupun dari pola hidup. Hal lain yang diamati oleh peneliti adalah keadaan suhu sekarang ini di wilayah kecamatan ketungau tengah pada umumnya terasa semakin panas, hal ini sedikit banyak dipengaruhi oleh minimnya hutan sebagai penyuplai oksigen segar dan sekaligus sebagai tempat konservasi tanah dan air.

\section{Aspek Ekonomi}

Perusahaan PT. Perdana Sawit Plantation memberikan dampak yang sangat berarti bagi perkembangan perekonomian warga masyarakat. Berdasarkan observasi peneliti, banyak sektorsektor ekonomi dibangun dengan adanya perusahaan seperti masyarakat dapat meningkatkan dalam usaha dagang sehingga memperlancar arus barang dan jasa di masyarakat. Dengan adanya akses prasarana jalan maka berakibat munculnya usaha di dalam transportasi darat sehingga dapat mengurangi frekuensi masyarakat di dalam menggunakan jalur sungai. Transportasi sungai biaya lebih mahal dibandingkan dengan transportasi darat, dengan demikian dapat menghemat pengeluaran masyarakat yang berpergian ke kota sintang.

Tujuan umum dari pendirian perusahaan adalah untuk kepentingan harus semua stakeholder yang ada. Tujuan dibidang ekonomi dapat berupa dalam bentuk lingkup yang lebih besar yaitu perekonomian nasional dan lingkup yang lebih sempit adalah untuk meningkat perekonomian masyarakat yang berada di wilayah operasi perusahaan. Secara nasional tentu produksi dari kelapa sawit dapat meningkat pendapatan domestik bruto sehingga dapat meningkatkan devisa Negara. Dampak keberadaan perusahaan perkebunan memberikan dampak multiplayer Effect bagi siklus perekonomian nasional, artinya dapat memberikan dampak secara tidak langsung kepada sektor-sektor yang lain di dalam sistem perekonomian. Dampak ekonomi bagi masyarakat tentunya dapat dilihat dari pertumbuhan perekonomian masyarakat, dalam hal peningkatan distribusi barang dan jasa. Di desa masyarakat yang membuka usaha toko bertambah dari sebelum ada perusahaan. Masyarakat yang berdagang memanfaatkan pangsa pasar dari perusahaan, pegawai-pegawai perusahaan dapat dijadikan konsumen bagi usaha-usaha dagang tersebut.

Penghasilan masyarakat juga dapat diperoleh dari produksi kelapa sawit bagi para petani pemilik kebun plasma. Sistem bagi hasil utuk kebun plasma dengan pola kemitraan antara perusahaan dengan masyarakat setempat mengacu kepada Peraturan Menteri Pertanian Nomor 26 tahun 2007 tentang pedoman perijinan Usaha Perkebunan. Pola kemitraan pengelolaan adalah untuk menjamin ketersediaan bahan baku, terbentuknya harga yang sesuai/wajar, pengembangan usaha, pendanaan, jangka waktu dan penyelesaian perselisihan yang ditandatangani kedua belah pihak dengan diketahui oleh Bupati. Perjanjian dilakukan secara tertulis dalam bentuk perjanjian yang berisikan hak dan kewajiban kedua belah pihak. Dalam pengembangan pola kemitraan, perusahaan akan menyiapkan dana untuk pembangunan kebun, sedangkan masyarakat akan menyerahkan lahan. Selanjutnya kebun akan dibagi menjadi dua bagian antara perusahaan dan masyarakat dengan perbandingan $70: 30$, dimana 70 bagian untuk perusahaan dan 30 bagian untuk masyarakat dengan sistem kredit yang disepakati.

Bagi masyarakat Desa,belum mengetahui dengan pasti mengenai pelaksanaan dari ketentuan mengenai pembagian hasil antara petani plasma dengan perusahaan, hal ini dikarenakan masih sulitnya memperoleh informasi dari ketua koperasi yang mengelola hasil produksi kebun plasma. Selama ini belum ada penjelasan yang dapat diketahui oleh masyarakat mengenai mekanisme perolehan hasil dari kebun plasma tersebut. Hal tersebut juga disampaikan oleh tokoh masyarakat bahwa masyarakat tidak mengetahui mekanisme pembagian yang sebenarnya dari pendapatan kebun plasma mereka. Kebanyakan masyarakat hanya sebagai penerima uang saja setiap periodenya tanpa mengetahui cara perhitungan dari penghasilan yang diterima. Dampak dari keberadaan perkebunan sawit juga berdampak pada pengelolaan dari masyarakat mengenai perkebunan, beberapa masyarakat yang memiliki keinginan dan kemampuan untuk membuka kebun sendiri juga dapat memperoleh pendapatan dari pengelolaan kebun secara swadaya. Hasil dari perkebunan sawit swadaya cukup berarti untuk menambah penghasilan keluarga petani selain penghasilan yang diperoleh dari sumber yang lainnya. Keberadaan perkebunan kelapa sawit juga sangat penting bagi warga masyarakat yang mengantungkan sumber pendapatannya dari upah dan gaji yang dibayarkan oleh perusahaan sebagai imbalan sebagai pegawai ataupun buruh diperusahaan. Upah atau gaji dari perusahaan bagi individu yang menjadi pegawai atau buruh perusahaan dapat memenuhi kebutuhan keluarga. Dengan demikian bagi masyarakat disekitar yang terlibat di perusahaan sebagai pekerja, 
terjadi transformasi pekerjaan dari sebelum berdirinya perusahaan. Sebelum ada perusahaan masyarakat secara umum bekerja secara swadaya mengelola alam, seperti bercocok tanam, menoreh karet, mengelola kayu untuk bahan bangunan, berkebun lada, dan sebagainya.

\section{KESIMPULAN DAN SARAN}

Perusahaan memiliki dampak positif terhadap berbagai aspek kehidupan di masyarakat, dampa positif tersebut merupakan suatu dampak yang memberikan keuntungan bagi masyarakat. Salah satu aspek penting yang berdampak adalah dampak pada aspek sosial. Pada aspek sosial terjadi perubahan pola kerja dan gaya hidup yang lebih mengarah kepada kreativitas, inovasi dan produktivitas kerja. Selain itu juga masyarakat dapat terbantu dengan adanya penyerapan tenaga kerja serta bantuan bagi masyarakat dari program CSR yang dilakukan oleh perusahaan. $\mathrm{K}$ o $\mathrm{n} \mathrm{t} \mathrm{r}$ i b u s i perusahaan perusahaan di bidang ekonomi adalah perusahaan turut serta memberikan manfaat kepada stakeholder-stakeholder terkait seperti memberikan deviden dari hasil operasi perusahaan kepada pemilik, penanam saham dan pemberian kompensasi kepada pegawai. Bagi masyarakat manfaat secara ekonomi yang dapat dinikmati adalah pembagian hasil dari bagi hasil kebun plasma bagi petani pemilik plasma. Kemudian terbukanya kesempatan untuk bisnis dagang bagi pelaku usaha dengan adanya proyek perkebunan, karena segmen pasarnya adalah para pegawai perusahaan selain masyarakat setempat. Disarankan

Tanggung jawab perusahaan yang sudah berjalan sebaiknya dapat lebih ditingkatkan lagi sehingga masyarakat dan stakeholder terkait lebih banyak merasakan manfaat dari keberadaan perusahaan. Selain itu perusahaan harus tetap menjalin komunikasi yang baik dan inten kepada semua pihak agar setiap persoalan yang dapat timbul dapat dicari solusinya melalui cara-cara terbaik.
Pengelolaan koperasi yang mengurus kebun plasma harus ditingkatkan dengan melakukan komunikasi dan transparansi kepada para petani pemilik kebun plasma termasuk rincian biaya pemeliharaan kebun dan keuntungan yang diperoleh dapat diketahui dengan jelas oleh petani pemilik kebun. Selain itu guna meningkatkan pendapatan para pegawai, sebaiknya perusahaan dapat meningkatkan atau memberikan kenaikan upah atau gaji secara berkala kepada kepada pegawai maupun buruh harian lepas agar kesejahteraan mereka dapat ditingkatkan.

\section{DAFTAR PUSTAKA}

Adit Agus Prastyo, 2010. Analisis Faktor-Faktor yang MempengaruhiTingkat Kemiskinan, (Semarang:UNDIPPRESS.

M. Sinaga Anggiat dan Sri Hadiati. 2001. Pemberdayaan Sumber Daya Manusia. Jakarta : Lembaga Administrasi Negara Republik Indonesia.

Mahmudah 2010. Psikologi Sosial, Malang: UIN Maliki Press.

Milman Yusdi. 2010. "Kamus Umum Bahasa Indonesia". Jakarta: Pustaka Sinar Harapan.

Resita,N.A,dkk.2014. Pola Interaksi Sosial Siswa Kelas Akselerasi.Jurnal PPKN UNJ Online.

Robbins SP, 2007. Perilaku Organisasi, Alih Bahasa Drs. Benyamin Molan Jakarta : Salemba Empat.

Sugiyono. 2011. Metode Penelitian Kualitatif, Kuantitatif dan $R$ \& D,: Alfabeta : Bandung.

Undang-Undang Nomor 23 tahun 1992, Tentang Kesehatan, Penerbit Ariloka, Surabaya

Departemen Pendidikan Nasional, 2003. UndangUndang Nomor 20 Tahun 2003, Tentang Sistem Pendidikan Nasional, Jakarta: Depdiknas. 